\title{
Regulatory Action of all trans Cancer Acid on Metastasis Induced Lung Cell Metabolic Changes during Implantation of B16F10 Cancer Cells in C57BL6 Mice
}

\author{
V.M. Berlin Grace ${ }^{1 *}\left(\mathbb{D}\right.$, D. David Wilson² ${ }^{2}$, S. Saranya ${ }^{1}$ and Rohit Peardon ${ }^{1}$ \\ ${ }^{1}$ Department of Biotechnology, Karunya Institute of Technology and Sciences, Coimbatore, India. \\ ${ }^{2}$ School of Science, Arts and Management, Karunya Institute of Technology and Sciences, Coimbatore, India.
}

\begin{abstract}
The changes that occur during metastasis lodging is under intense research now to develop preventive new drugs to fight against the deadly metastasis. The molecular drug, all trans Retinoic Acid (ATRA) has regulatory effects on signal mediated metabolism. In this study, we have analyzed the metastasis facilitating metabolic changes in mice lung when a highly metastatic melanoma cell line (B16F10) having potency to lodge in lung was implanted via tail vein injection into C57BL/6 mice $\left(1 \times 10^{6} \mathrm{cells} / \mathrm{ml}\right.$ in PBS). One group of implanted mice were treated with $0.60 \mathrm{mg}$ of ATRA per $\mathrm{Kg}$ body weight daily for 21 days. The alteration of protein, enzymatic and non-enzymatic antioxidants (SOD, Catalase, GPX, GSH) levels and the lipid profile with cholesterol level were evaluated in the lung tissues. The ATRA treatment caused $62.16 \%$ inhibition on metastatic nodule formation. Compared to normal mice, the cancer control mice showed an increased $\left(p \leq 0.01^{* *}\right)$ total protein, LPO and NO and a decreased antioxidant. In ATRA treated group, all these levels were reverted to near normal levels with a high significance $\left(p \leq 0.01^{* *}\right)$ difference from untreated cancer mice. The lipid profile and cholesterol level also were altered in cancer and were normalized in ATRA treated group with high significance $\left(p \leq 0.01^{* *}\right)$. All these results implies that the metabolic changes induced in the lung tissue during metastatic lodging of melanoma cells were prevented and regularized by the ATRA treatment in vivo which give a scope of anti-metastatic therapy using ATRA.
\end{abstract}

Keywords: Lung metastasis, ATRA, C57BL/6 mice, melanoma cell line, Metabolism change

*Correspondence: berlinbiochem@gmail.com; Tel: +91-9894051175

(Received: November 18, 2020; accepted: May 12, 2021)

Citation: Grace VMB, Wilson DD, Saranya S, Peardon R. Regulatory Action of all trans Cancer Acid on Metastasis Induced Lung Cell Metabolic Changes during Implantation of B16F10 Cancer Cells in C57BL6 Mice. J Pure App/ Microbiol. 2021;15(2):743-751. doi: 10.22207/JPAM.15.2.26

(C) The Author(s) 2021. Open Access. This article is distributed under the terms of the Creative Commons Attribution 4.0 International License which permits unrestricted use, sharing, distribution, and reproduction in any medium, provided you give appropriate credit to the original author(s) and the source, provide a link to the Creative Commons license, and indicate if changes were made. 


\section{INTRODUCTION}

Cancer is a multi-factorial disorder, originating due to infection, inflammation, pollution-smoke, radiation, oxidative stress, diet, life style and genetics (Anand et al). Most of the lung cancer patients when diagnosed are at metastasis stage as it metastasizes very fast which may be due to rich blood flow. Hence, now the cancer researchers are concentrating more on management of cancer metastasis, fast progression as well as the associated changes in the body. The Vitamin A active metabolite, ATRA is a molecular therapeutic agent which has control over several genes involved in the molecular pathogenesis of cancer progression and metastasis (Cui et al) by binding to its receptor RARs and regulating target genes (Aranda et al.). ATRA has shown vital regulatory role in embryonic development of several tissues and organs (Romero et al). As an example, the functional retinoic acid response elements (RAREs) was found within flanking sequences of some of the most 3' Hox genes (Marshall et al.) which are the responder to ATRA during early embryonic development stages in control anterior/posterior patterning (Holland et al). ATRA alone or in combination is now used as a potent therapeutic agent for Acute Promyelocytic Leukaemia ( $\mathrm{APL}$ ) complete remission rate as high as $85 \%$ to $95 \%$ (Osman et al; Zhang et al and Chou et $a l)$ and was found to induce differentiation (Zuccari et al) and apoptosis (Altucci et al.). ATRA has been proven to treat vascular disorders and abnormal angiogenesis (Maiti et al.).

The oxidative stress and inflammatory mediators generated during cancer development aggravate the lung cancer progression and enhance the metastasis (Valavanidis et al.). The oxidative stress markers and inflammatory mediators set up a favourable tumour microenvironment at cancer initiation itself and enhance progression, promote angiogenesis, invasion, tumour cell migration, leading to metastasis. (Vaidya et al). Some studies have shown a relationship between retinoic acid and the generation of nitric oxide (NO) (Rafa et al., Grosjean et al., Hirokawa et al., Seguin et al.), prostaglandins (Mamidi et al.; Devaux et al., Hill et al.) and the expression of cyclooxygenase 1 (COX-1) (Habib et al, Nusing et $a l)$ and COX-2 (Kanekura et al). Retinoid have various effects on cytokines by decreasing IL-12 and IFN as well as increasing IL-4 (Villarroya et al). Cell line implantation and metastasis is reported to generate several reactive species and radicals and the cancer condition itself reduces the antioxidant enzyme level in our body. However, it is unknown whether oxidative stress is the cause or the consequence of disease, but Reactive Oxygen Species (ROS) promotes tumor progression and make up the tumor microenvironment (Liou and Storz, 2010; Weinberg et al) which promote immune cell infiltration (Kotsafti et al). RoS activate cell survival signalling, leading to cancer cell migration and metastasis (Aggarwal et al.). However, reduction of these stress parameters and inflammation mediators help to manage the metastatic complications in lung cancer. Vitamin $A$ and retinoid family have been traditionally recognized as chain breaking anti-oxidant or redoxactive molecules (Khaper et al, Mantymaa et al). ATRA at very low level has enhanced the levels of MnSOD2 and Cu.ZnSOD1 to protect from oxidative damage in a neuronal cell line study (Ahlemeyer et al.). Lung metastasis involve oxidative stress and inflammation (Li et al.).

Lipids as the key membrane composition, source of energy and regulator of signal transduction pathways, plays vital role in cancer progression and undergo rapid change both at molecule and gene levels in cancer (Watkins et al). Study in mice has shown that the treatment with ATRA reduced body weight and adiposity independent of changes in food intake (Puigserver et al.) and has improved the glucose tolerance level (Felipe et al). ATRA has been proven to induce body fat loss which very well correlated with an activation of brown adipose tissue (BAT) (Bonet $e t$ al. and Puigserver et al.) and it was also reported to reduce adipogenic/lipogenic capabilities (Ribot $e t$ al.), thereby enhancing the oxidative metabolism and thermo genesis in white adipose tissue (WAT) depots, leading to fatty acid mobilization as well as healthy oxidation in other tissues (Mercader et al., 2006). Thus retinoic acid was found to regulate the adipose tissue development as well as deposition of lipid at different tissues (Hiroshi et al.).

This study was therefore designed to analyze the vital changes happening in the lung of C57BL6 mice during cancer cell line implantation 
and the regulatory role of ATRA in this condition by considering all these findings regarding metastasis associated metabolic and physiologic changes.

\section{MATERIAL AND METHODS Animals}

Four to six weeks old mice (C57BL/6) were procured from the National Institute of Nutrition, Hyderabad, and subjected in this study. The mice were maintained in animal house at suitable condition as per the guidelines of CPCSEA during the experimental period by providing normal feed with water ad libitum.

Chemicals

ATRA was purchased from Sigma Chem. Co. (St. Louis, MO) and the other chemicals of analytical grade used were purchased from Himedia, India.

Cancer Cells

The melanoma cell line (B16F10) used for developing lung metastatic cancer in mice was obtained from the National Centre for Cell Science, Pune, India and sub-cultured in buffered medium (RPMI1640), supplemented with antibiotic, penicillin and streptomycin. They were recovered by harvesting with trypsin and EDTA and then (PBS, $\mathrm{pH}$ 7.4) wash was given.

\section{Study Design and Groups}

Four experimental groups (6 C57BL/6 mice per group) were included in this study. The group 1 mice was maintained as normal group and the mice of groups 2-4 were injected via tail vein with $0.1 \mathrm{ml}$ of B16F10 melanoma cells $\left(1 \times 10^{6}\right.$ cells/ $\mathrm{ml}$ in PBS) to develop metastatic mice model. The group 3 and 4 mice were simultaneously treated with i.p injection of $0.1 \mathrm{ml}$ Olive oil and ATRA ( 0.60 $\mathrm{mg}$ per Kg body weight) in olive oil respectively for 21 consecutive days as per the literature (Suzuki et al.). Furthermore no mortality or behavioral changes were shown by the mice until 50 days of observation in acute toxicity study carried out earlier for the dose up to $1 \mathrm{mg} / \mathrm{Kg}$ body weight. The protocol for these experiment was followed in line with the guidelines of CPCSEA and the approval for this study was obtained from the Institutional Animal Ethical Committee of Karunya University [IAEC/KU/BT/12/019]. On the 22nd day of metastasis induction and treatment, all the mice were sacrificed. The lung tissues were excised out, washed and observed visually through petri dish glass for metastatic nodules to count. From the number of nodules, we have calculated the percent of inhibition of nodule formation :

Inhibition Percent (\%) = No. of nodules in metastasis control - No. of nodules in treated/ No. of nodules in metastasis control $X 100$

Then a small portion of it was cut, placed in a buffer formalin (10\%), and embedded in paraffin for histologic studies. The remaining portion of lung tissues from each mouse were subjected to other analyses as detailed below.

Group 1:Normal mice

Group 2: B16F10 melanoma cell line implanted metastasis control mice

Group 3: B16F10 melanoma cell line implanted mice + Olive oil treatment

Group 4: B16F10 melanoma cell line implanted mice + ATRA treatment

Estimation of ATRA level in the tissue of lung

Lung tissues were homogenized with $10 \%$ ascorbic acid and ethanol. After vortexing, it was subjected to lipid extraction with $\mathrm{n}$-hexane ( 2 $\mathrm{ml}$ ), then vortexed. The hexane layer was collected after centrifugation for 10 minutes ( $2000 \mathrm{rpm}$ ) and air dried. The ATRA concentration in the residue after re-dissolving it in methanol $(250 \mu \mathrm{l})$ was then analysed using reversed phase HPLC system. The ATRA was detected at a wavelength of 310 $\mathrm{nm}$ with a mixture of acetonitrile in 4.5 to 6.5 ratio, run in the Phenomenex Luna column (250 $\mathrm{mm} \times 4.6 \mathrm{~mm}$ ) at $1 \mathrm{ml} / \mathrm{minute}$ flow rate. The peak area was calculated from the standard ATRA (400 to $2000 \mathrm{ng} / \mathrm{ml}$ ).

Total protein assay in lung tissues

A portion of lung tissue was homogeneized with buffer and the supernatant was separated by centrifugation. Then the total protein level was estimated against the standard protein bovine serum albumin (BSA) by the widely used standard method (Lowry et al.) and the optical density was measured at $680 \mathrm{~nm}$. From the standard graph obtained from the increasing concentrations of standard BSA, the level of protein present in the lung tissue extract was calculated and expressed in $\mu \mathrm{g} / \mathrm{g}$ tissue.

Evaluation of oxidative stress levels in lung tissue

The lung tissue was homogenised and the supernatant after centrifugation was subjected to analysis of various biochemical parameters which are related to oxidative stress induced in lung 
during implantation of metastatic cell line. The assays for the following enzymatic antioxidants were performed using standard colorimetric methods described by the researchers in very early years as follows: The method described by Kakkar et al., was used for the assay of Super Oxide Dismutase (SOD)(Kakkaret al.). The Catalase assay was performed as describe previously (Sinha et al.). The Glutathione Peroxidase (GPX) assay was carried out by following the relevant literature (Rotruck et al.).

Similarly, the non-enzymatic antioxidant Glutathione (GSH) estimation was done in the supernatant of TCA $(10 \%)$ precipitated homogenate by following the standard colorimetric method (Ellman et al.) and from the plotted standard graph and from which the GSH level in sample was calculated.

The extent of lipid peroxidation in lung tissue due to metastasis was assessed by measuring the production of thiobarbituric acid reactive substances (TBARS) by following the standard method (Ohkawa et al.) using MDA as standard. The assay for the generated nitric oxide (NO) was carried out in $250 \mu \mathrm{l}$ of lung tissue homogenate by incubating it with Griess reagent for 15 minutes and reading at $546 \mathrm{~nm}$ (John et al.)

\section{Lipid profiling}

The blood serum of experimental mice were subjected to lipid profiling along with estimation of total cholesterol level by following the standard Zak's method. Lipid profiling was done with the use of "Erba lipid profile kit. Briefly, the reagent was mixed with serum and the absorbance was read using colorimeter at $505 \mathrm{~nm}$ after 5 minutes incubation $\left(37^{\circ} \mathrm{C}\right)$.

\section{RESULTS}

\section{Metastatic nodules formed in lung}

The number of nodules formed due to metastatic lodging in lung of all mice was visually counted and the mean number of nodules in each group of mice is given in Table 1. The effect of ATRA treatment on prevention was then calculated by comparing with the number of nodules found in the lung of metastasis control mice as follows and expressed as percent inhibition in Table 1.

The mean values given are from 6 mice and the $p$ value is considered Non significant if it is $>0.05^{\text {ns }}$; means significant $(p \geq 0.05)$, and ${ }^{* *}$ means a highly significant $(p \geq 0.01)$

\section{ATRA and total protein in lung tissue}

The ATRA peak was obtained at RT value of 4.5 and from the standard calibration curve.

Table 1. Number of nodules found on lung and the percent inhibition by ATRA

\begin{tabular}{lll}
\hline Groups & $\begin{array}{l}\text { Mean number } \\
\text { of nodules }\end{array}$ & $\begin{array}{l}\text { Inhibition } \\
(\%)\end{array}$ \\
\hline 1 - Normal & Nil & NA \\
2 - Metastasis control & $59.52 \pm 01$ & NA \\
$3-$ Metastasis + vehicle treated & $56.61 \pm 11^{\text {ns }}$ & 4.88 \\
$4-$ Metastasis + ATRA treated & $22.52 \pm 07^{* *}$ & 62.16 \\
\hline NA - Not applicable & &
\end{tabular}

Table 2. The total protein level in lung tissue

\begin{tabular}{lll}
\hline Groups & $\begin{array}{l}\text { Mean protein } \\
\text { level }(\mu \mathrm{g} / \mathrm{g})\end{array}$ & $\begin{array}{l}\text { ATRA level } \\
(\mu \mathrm{g} / \mathrm{ml} \text { homogenate })\end{array}$ \\
\hline 1 - Normal & $24.23 \pm 12$ & $0.223 \pm 0.05$ \\
2 - Metastasis control & $47.32 \pm 10^{\mathrm{a}^{* *}}$ & 0 \\
3 - Metastasis + vehicle treated & $46.21 \pm 17^{\mathrm{a}^{* *} \mathrm{~b} n}$ & 0 \\
4 - Metastasis + ATRA treated & $31.22 \pm 06^{\mathrm{a}^{*}, \mathrm{~b} * *}$ & $0.476 \pm .08^{\mathrm{a}^{* *}}$ \\
\hline NA - Not applicable & & \\
\hline Journal of Pure and Applied Microbiology & 746 & www.microbiologyjournal.org
\end{tabular}


Normally the level of ATRA will be maintained in a lower quantity in serum and in lung. Hence in our study also the quantity of ATRA present in the lung of normal mice was found to be very low $(0.223$ \pm 0.05 ) whereas, in the metastasis control group and the olive oil treated group the ATRA level was completely reduced and was undetectable. But the treatment with ATRA has shown an elevation $(p \geq$ $\left.0.01^{* *}\right)$ in the level of ATRA than the normal level in group 4 animal as shown in Table 2.

The increase in total protein level when compared to normal mice was found to be highly significant $\left(p \geq 0.01^{* *}\right)$ in the metastasis control group as well as in olive oil treated group whereas the increase in ATRA treated group was minimum $\left(p \geq 0.05^{*}\right)$. ATRA treated group shown a greater difference from control group while a non-significance was observed in olive oil treated group as shown in Table 2. This may be resulted from the cell physiologic/functional changes due to increase in cell surface receptor, glycoproteins, lytic enzymes such as collagenase, cathepsin, plasminogen activator (cleave peptide bond) which favour mobility and dissemination of metastatic cells.

The values given are the mean \pm SD of 6 mice and the $p$ value is considered Non significant if it is $>0.05^{\text {ns }}$; significant if it is $\geq 0.05^{*}$, and highly significant if it is $\geq 0.01^{* *}$. ${ }^{\text {a Group }} 1$ Normal Vs Groups 2-4; 'Group 2- Control Vs Groups 3 and 4 Profile of Oxidative Stress Markers in the Lung Tissue

In this study we have observed a significant level of changes in lung antioxidant levels in the experimental groups during metastasis (Table 3$)$. A highly significant $\left(p \geq 0.01^{* *}\right)$ reduction in antioxidant enzymes was observed in metastasis control groups. Comparatively, the ATRA treated group has shown a highly significant increase in all these enzymes while, in the vehicle treated group, no significant reduction was observed in olive oil treated group (Table 3).

The mean values of 6 mice are given with SD. ${ }^{\text {ns }}$ means not significant $(p>0.05) ; *$ means

Table 3. Levels of antioxidants in the lung tissue

\begin{tabular}{|c|c|c|c|c|}
\hline Groups & $\begin{array}{c}\text { SOD } \\
\text { (U/Mg protein) }\end{array}$ & $\begin{array}{c}\text { Enzymatic } \\
\text { Catalase } \\
\text { ( } \mu \mathrm{M} / \mathrm{Mg} \text { protein) }\end{array}$ & $\begin{array}{c}\text { GPX } \\
\text { ( } \mu \mathrm{g} / \mathrm{Mg} \text { protein) }\end{array}$ & $\begin{array}{c}\text { Non-enzymatic } \\
\text { GSH } \\
\text { ( } \mu \mathrm{g} / \mathrm{Mg} \text { protein) }\end{array}$ \\
\hline 1 - Normal & $4.35 \pm 0.02$ & $0.091 \pm 0.18$ & $43.17 \pm 0.14$ & $1.93 \pm 0.05$ \\
\hline 2 - Metastasis control & $1.87 \pm 0.03^{a^{* *}}$ & $0.031 \pm 0.02^{\mathrm{a}^{* *}}$ & $19.09 \pm 0.08^{a^{* *}}$ & $0.52 \pm 0.16^{\mathrm{a}^{* *}}$ \\
\hline 3-Metastasis + vehicle treated & $1.75 \pm 0.06$ bns & $0.037 \pm 0.04^{\mathrm{bns}}$ & $19.21 \pm 0.13^{\text {bns }}$ & $0.59 \pm 0.13^{\mathrm{bns}}$ \\
\hline $4-$ Metastasis + ATRA treated & $3.65 \pm 0.11^{b^{* *}}$ & $0.072 \pm 0.05^{b^{* *}}$ & $36.05 \pm 0.07^{b^{* *}}$ & $1.22 \pm 0.06^{b^{* *}}$ \\
\hline
\end{tabular}

Table 4. Extent of lipid peroxidation and Nitric Oxide levels in the lung tissue

\begin{tabular}{lcc}
\hline Groups & LPO activity $(\mathrm{nM} / \mathrm{g})$ & NO level $(\mu \mathrm{M} / \mathrm{g})$ \\
\hline 1 - Normal & $12.21 \pm 0.07$ & $1.39 \pm 0.07$ \\
2 - Metastasis control & $40.33 \pm 0.04^{\mathrm{a}^{* *}}$ & $3.98 \pm 0.12^{\mathrm{a}^{* *}}$ \\
3 - Metastasis + vehicle treated & $40.52 \pm 0.02^{\mathrm{bns}}$ & $3.65 \pm 0.11^{\mathrm{bns}}$ \\
4 - Metastasis + ATRA treated & $20.14 \pm 0.09^{\mathrm{b}^{* *}}$ & $2.04 \pm 0.08^{\mathrm{b}^{* *}}$ \\
\hline
\end{tabular}

Table 5. Lipid profile and cholesterol levels in the serum (mg/dl)

\begin{tabular}{lccccc}
\hline Groups & Cholesterol & TGL & HDL & LDL & VLDL \\
\hline 1 - Normal & $110 \pm 2$ & $97 \pm 4$ & $42 \pm 3$ & $67 \pm 1$ & $21 \pm 2$ \\
2 - Metastasis control & $225 \pm 1^{\mathrm{a}^{* *}}$ & $32 \pm 2^{\mathrm{a}^{* *}}$ & $18 \pm 2^{\mathrm{a}^{* *}}$ & $107 \pm 2^{\mathrm{a}^{* *}}$ & $41 \pm 1.5^{\mathrm{a}^{* *}}$ \\
3 - Metastasis + vehicle treated & $223 \pm 2^{\text {bns }}$ & $31 \pm 3^{\text {bns }}$ & $18 \pm 3^{\text {bns }}$ & $105 \pm 1^{\text {bns }}$ & $40 \pm 3^{\text {bns }}$ \\
4 - Metastasis + ATRA treated & $130 \pm 1^{\mathrm{b}^{* *}}$ & $85 \pm 1^{\mathrm{b**}}$ & $36 \pm 1^{\mathrm{b}^{\text {b* }}}$ & $78 \pm 3^{\mathrm{b}^{* *}}$ & $29 \pm 2^{\mathrm{b}^{* *}}$ \\
\hline Journal of Pure and Applied Microbiology & & 747 & & www.microbiologyjournal.org
\end{tabular}


significant $(p \geq 0.05) * *$ means highly significant ( $p$ $\geq 0.01$ ). Also, ${ }^{a}$ Group 1 Normal Vs Groups 2 Control; ${ }^{\mathrm{b}}$ Group 2 Control Vs Groups 3 and 4 treatments

We have also observed a significant levels of changes in the extent of cell membrane lipid peroxidation as well as the reactive NO radical in the lung tissues among the groups of experimental mice during metastasis as shown in Table 4. The extent of lipid peroxidation and the NO level have increased in the metastasis control group in a highly significant $\left(p \geq 0.01^{* *}\right)$ level while ATRA treated group has shown a highly significant ( $p$ $\geq 0.01^{* *}$ ) reduction than control. However, the olive oil treated group showed only non-significant difference from the control group.

The mean values from 6 mice are given with SD. ${ }^{\text {ns }}$ means not significant $(p>0.05) ;{ }^{*}$ means significant $(p \geq 0.05) * *$ means highly significant ( $p \geq 0.01$ ). Here, ${ }^{\mathrm{a} G r o u p ~} 1$ Normal Vs Groups 2 Control; ${ }^{b}$ Group 2 Control Vs Groups 3 and 4 treatments

Lipid Profile and Level of Cholesterol in the Lung Tissue

The results of lipid profile and cholesterol are given in Table 5 . A highly significant $\left(p \geq 0.01^{* *}\right)$ increase was shown in cholesterol and HDL levels in the metastasis control. On contrary to it, a highly significant $\left(p \geq 0.01^{* *}\right)$ decrease was noticed for TGL in the control group. All these changes were brought to near normal level in the ATRA treated group while the olive oil treatment which showed similar alterations like control group could not make any reversion in the levels.

The data is given as mean values from 6 mice with SD. ${ }^{n s}$ means not significant $(p>0.05)$; * means significant $(p \geq 0.05) * *$ means highly significant $(p \geq 0.01)$. Here, aroup 1 Normal Vs Groups 2 Control; ' Group 2 Control Vs Groups 3 and 4 treatments

\section{DISCUSSION}

It is understood from the literature that most of the physiologic regulatory functions of Vitamin A mainly metabolism, cell growth, apoptosis and reproduction are exhibited through its one of the active metabolite, ATRA along with other retinoid (Mangelsdorf et al.). The chemotherapeutic role of ATRA as a cell differentiating molecular agent has become well known due to its efficient action on treating Acute
Promyelocytic Leukemia (APL) and also by its key role in treating many other deadly diseases (Farooqui et al.). In addition to its therapeutic role ATRA has crucial role as chemo preventive agent against the development of cancer, angiogenesis and inflammation. In the past work which has been done to study the anti-inflammatory effect of ATRA in inflammatory arthritis has shown that the incidence of arthritis were lower in mice treated with ATRA than a normal mice (Yuji et al.). Some of the molecular actions of ATRA treatment on cancer were found to be arresting cell cycle at $\mathrm{G} 1$ as well as prolonging cell division rather killing tumor cells which is an identity for molecular therapy and also it could reduce DNA synthesis as well as colony formation. Being a differentiating agent it could also induce morphological changes in tumour cells (Wu et al.).

The cellular ATRA level is tightly regulated by two types of binding proteins such as CRABP I and II which direct it to nucleus for interaction with its high affinity receptors RARs $(\alpha, \beta$, and $\gamma)$ for exhibiting molecular action on target cells along with its isomer, 9-cis-retinoic acid which can also bind to RXRs ( $\alpha, \beta$, and $\gamma$ ) (Chen et al.; Mangelsdorf et al.; Heyman et al.). According to the variation in receptor types availability in each organ ATRA exhibits regulation of various cellular functions. Presently intense research is focused towards the therapeutic efficiency of ATRA for many solid cancers in addition to APL and vascular disorders (Zuccari et al.; Maiti et al.).

Recent studies have highlighted that the hypoxia condition in cancer cell infiltration induces ROS production and inflammatory responses which facilitate the tissue damage mediated migration of cancer cells, resulting in lung metastasis (Li et al.). A recent mice model study also has demonstrated that the hypoxia induced oxidative stress and inflammatory response promoted melanoma lung metastasis (Li et al.).In our study ATRA has shown an impressive antioxidant activity to reduce the free radicals present in the body by the different antioxidant enzymes. The previous reports states that the free radicals can damage the DNA and can cause a tumour cell proliferation. When ATRA was given to the cancer induced mice it has shown an impressive enzymatic antioxidant activity. Our study was done on SOD, Catalase, NO, GPx, GSH, LPO and the results states that ATRA has the 
antioxidant property.

When these antioxidant levels are reduced in living systems, the excess free radicals generated during cancer metastasis and progression via activated LPO action as we have demonstrated in our study will facilitate further progression and establishment of cancer in metastasized site. It was reported by other studies also that the oxidative stress created by the free radicals have implication in the pathogenesis of many clinical disorders, including cancer (Narendirakannan et al.). They also have highlighted that there should be enough antioxidants or natural agents that are capable of augmenting the activity antioxidant enzymes to prevent implications of free radicals including cancer progression. In addition, the membrane lipids also plays key role in generating such free radicals as well as in signal transduction leading to alteration in cell growth and apoptosis (Watkins et al.).

On the basis of the previous reviews, our idea of doing the lipid profiling was to identify that when ATRA is given to the normal mice and the cancer cell line implanted mice what will be the effect on the lipid content of the body. There is no adverse change in the lipid content of the body for ATRA treatment however, there is a significant decrease in the cholesterol level in mice and increase in the LDL level. The result shows that ATRA has no adverse effect on the lipid content of the body and there were no significant side effect seen in ATRA treated mice.

On the basis of the result which came out of different parameter done to analyse the physiological effect of ATRA on lung cancer in mice has shown a potent effect of ATRA.

Since ATRA is already been use as a chemo-preventive drug for the APL, it can be used for the treatment of lung cancer also to prevent the metastasis and progression. Though ATRA is a lipid, by lipid profiling it is seen that it has not shown any adverse effect on the lipid content in mice body. The conclusion of all these parameters is that ATRA has potent anti-cancer drug properties against lung metastasis.

\section{ACKNOWLEDGMENTS}

The authors acknowledge the financial support given by the Management of Karunya Institute of Technology and Sciences via Karunya
Short Term Research. The shared facilities from the Cancer Nano-therapeutic Research Centre established with the funding of the Department of Science and Technology - Science and Engineering Research Board and the Department of Biotechnology New Delhi.

\section{CONFLICT OF INTEREST}

The authors declare that there is no conflict of interest.

\section{AUTHORS' CONTRIBUTION}

All authors designed the experiments. SS \& RP performed the experiments. VMBG analyzed the data and DDW wrote the manuscript along with BG. All authors read and approved the manuscript.

\section{FUNDING}

Management of Karunya Institute of Technology and Sciences via Karunya Short Term Research Grant (KSTRG:2008-09). Funding of the Department of Science and Technology - Science and Engineering Research Board (DST-SERB-Ref: No.SB/YS/LS-252/2013, dated 15 May, 2014) and the Department of Biotechnology (Ref. No.: BT/ PR14632/NNT/28/824/2015, dated 02-09-2016) New Delhi.

\section{DATA AVAILABILITY}

All datasets generated or analyzed during this study are included in the manuscript.

\section{ETHICS STATEMENT}

This study was carried out in accordance with the recommendations of NIH guidelines for animal use, Animal Care and Use Committee (NIH). The protocol for these experiment was followed in line with the guidelines of CPCSEA and the approval for this study was obtained from the Institutional Animal Ethical Committee of Karunya University [IAEC/KU/BT/12/019].

\section{REFERENCES}

1. A Vaishali, HS Tuli, A Varol, et al. Role of Reactive Oxygen Species in Cancer Progression: Molecular Mechanisms and Recent Advancements. Biomolecules. 2019; 9:735. doi: 10.3390/biom9110735

2. Ahlemeyer B, Bauerbach E, Plath $\mathrm{M}$, et al. Retinoic acid reduces apoptosis and oxidative stress by preservation of SOD protein level. Free RadicBiol 
Med. 2001;30:1067-1077. doi: 10.1016/S08915849(01)00495-6

3. Ahlemeyer B, Krieglstein J. Inhibition of glutathione depletion by retinoic acid and tocopherol protects cultured neurons from staurosporine-induced oxidative stress and apoptosis. Neurochem Int. 2000; 36:1-5. doi: 10.1016/S0197-0186(99)00101-1

4. $\quad$ Altucci L, Rossin A, Raffelsberger W, et al. Retinoic acid-induced apoptosis in leukemia cells is mediated by paracrine action of tumor-selective death ligand TRAIL. Nat Med. 2001;7:680-686. doi: 10.1038/89050

5. Anand $P$, Kunnumakkara $A B$, Kunnumakara $A B$ et al. Cancer is a preventable disease that requires major lifestyle changes. Pharm. Res. 2008;25(9): 2097-116. doi: 10.1007/s11095-008-9661-9

6. Aranda A, Pascual A. Nuclear hormone receptors and gene expression. Physiol Rev. 2001;81:1269-1304. doi: 10.1152/physrev.2001.81.3.1269

7. Balakrishnan N, Panda A, Raj N, Shrivastava A, Prathani R. The evaluation of nitric oxide scavenging activity of Acalyphaindica Linn root. Asian J Res Chem. 2009;2(2): 148-150.

8. Bonet ML, Ribot J, Felipe E, Palou A. Vitamin A and the regulation of fat reserves. Cell Mol Life Sci. 2003; 60:1311-1321. doi: 10.1007/s00018-003-2290-x

9. Chen $Y$, Dokmanovic $M$, Stein WD, Ardecky RJ, Roninson IB, Agonist and antagonist of retinoic acid receptors cause similar changes in gene expression and induce senescence-like growth arrest in MCF-7 breast carcinoma cells. Cancer Research. 2006;66 (17): 8749-8761. doi: 10.1158/0008-5472.CAN-06-0581

10. Chou WC, Dang CV. Acute promyelocyticleukemia: recent advances in therapy and molecular basis of response to arsenic therapies. Curr Opin Hematol. 2005;12:1- 6. doi: 10.1097/01. moh.0000148552.93303.45

11. Cui J, Gong M, He Y, Li Q, He T, Bi Y. All-trans retinoic acid inhibits proliferation, migration, invasion and induces differentiation of hepa1-6 cells through reversing EMT in vitro. International Journal of Oncology. 2016;48(1): 349-357. doi: 10.3892/ijo.2015.3235

12. Devaux $Y$, Zangrando J, Schroen $B$, et al. Long noncoding RNAs in cardiac development and ageing. Nat Rev Cardiol. 2015;12(7):415-25. doi: 10.1038/ nrcardio. 2015.55

13. Ellman GL, Courtney KD, Andresjr V, Featherstone RM. A new and rapid colorimetric determination of acetylcholinesterase activity. BiochemPharmacol. 1961;7:88-90. doi: 10.1016/0006-2952(61)90145-9

14. Farooqui AA, Yang HC, Horrocks L. Involvement of phospholipase $A 2$ in neurodegeneration. NeurochemInt. 1997;30:517-522. [PubMed: 9152992] doi: 10.1016/S0197-0186(96)00122-2

15. Felipe F, Bonet ML, Ribot J, Palou A. Modulation of resistin expression by retinoic acid and vitamin $A$ status. Diabetes. 2004;53:882-889. doi: 10.2337/ diabetes.53.4.882

16. Grosjean F, Cerneau P, Bourdillon A, Bastianelli D, Peyronnet $C$, Duc G. Feeding value, for pig, of near isogenic faba beans containing or not tannins and with high or low levels of vicine or convicine. J. Rech. Porc. 2001;33: 205-210.
17. Habib A, Hamade E, Mahfouz R, Nasrallah MS, de Thé $\mathrm{H}$, Bazarbachi A. Arsenic trioxide inhibits ATRA-induced prostaglandin E2 and cyclooxygenase-1 in NB4 cells, a model of acute promyelocyticleukemia. Leukemia. 2008; 22(6):1125-30. PMID: 18354491. doi: 10.1038/ leu.2008.59

18. Heyman RA, Mangelsdorf DJ, Dyck JA et al. 9-cis retinoic acid is a high affinity ligand for the retinoid $X$ receptor. Cell. 1992;68:397-406. doi: 10.1016/00928674(92)90479-V

19. Hirokawa K, Masanori Utsuyama, Yi-Xin Zeng, ChieriKurashima, Kasai Michiyuki, Immunological alterations with aging-laying a stress on recent progress in Japan, Archives of Gerontology and Geriatrics. 1994;19(2):171-183. doi: 10.1016/01674943(94)90038-8

20. Ogata HY, Oku H. The effects of dietary retinoic acid on body lipid deposition in juvenile red sea bream (Pagrus major); a preliminary study. Aquaculture. 2001;193(34): 271-279. doi: 10.1016/S0044-8486(00)00496-8

21. Holland LZ. A chordate with a difference. Nature. 2007;447(7141): 153-155. PMID 17495912. doi: 10.1038/447153a

22. Kakkar P, Das B, Viswanathan PN. A modified spectrophotometric assay of superoxide dismutase. Indian J BiochemBiophys. 1984;21(2):130-2. PMID: 6490072.

23. Kanekura T, Higashi Y, Kanzaki T. Inhibitory effects of 9-cis-retinoic acid and pyrrolidinedithiocarbamate on cyclooxygenase (COX)-2 expression and cell growth in human skin squamous carcinoma cells. Cancer letters. 2000;161:177-83. doi: 10.1016/\$0304-3835(00)006042

24. Andromachi K, Scarpa M, Castagliuolo I, Scarpa M. Reactive Oxygen Species and Antitumor ImmunityFrom Surveillance to Evasion. Cancers. 2020;12:1748. doi: $10.3390 /$ cancers 12071748

25. Li L, Ren F, Qi C, et al. Intermittent hypoxia promotes melanoma lung metastasis via oxidative stress and inflammation responses in a mouse model of obstructive sleep apnea. Respir Res. 2018; 19:28. doi: 10.1186/s12931-018-0727-x

26. Liou GY, Storz P. Reactive oxygen species in cancer. Free Radic Res. 2010;44(5):479-496. doi: 10.3109/10715761003667554

27. Lowry OH, Rosebrough NJ, Farr AL, Randall RJ. Protein measurement with the Folin phenol reagent. J Biol Chem. 1951;193(1):265-75. PMID: 14907713. doi: 10.1016/S0021-9258(19)52451-6

28. Maiti TK, Ghosh KS, Debnath J, Dasgupta S. Binding of all-trans retinoic acid to human serum albumin: Fluorescence, FT-IR and circular dichroism studies. Int J BiolMacromol. 2006;38:197-202. doi: 10.1016/j. ijbiomac.2006.02.015

29. Srinivas M, PJH Thomas, H Reinhard, ZH Löms, Marion F. All-trans retinoic acid up-regulates Prostaglandin-E Synthase expression in human macrophages. Immunobiology. 2012;217(6): 593-600. doi: 10.1016/j. imbio.2011.10.022

30. Mangelsdorf DJ, Borgmeyer U, Heyman RA, et al. Characterization of three RXR genes that mediate the action of 9-cis retinoic acid. Genes Dev. 1992;6:329- 
344. doi: 10.1101/gad.6.3.329

31. Mantymaa P, Guttorm T, Siitonen T, et al. Cellular redox state and its relationship to the inhibition of clonal cell growth and the induction of apoptosis during all-trans retinoic acid exposure in acute myeloblasticleukemia cells. Haematologica. 2000, 85:238-245.

32. Marshall H, Morrison A, Studer M, Pöpperl H, Krumlauf R. Retinoids and Hox genes. The FASEB Journal. 1996;10: 969-978. doi: 10.1096/fasebj.10.9.8801179

33. Mercader J, Ribot J, Murano I et al. Remodeling of white adipose tissue after retinoic Acid administration in mice. Endocrinology. 2006;147:5325-5332. doi: 10.1210/en.2006-0760

34. Thangavelu NR, Sorimuthu S. Biochemical evaluation of the protective effect of Aegle marmelos (L.), Corr. leaf extract on tissue antioxidant defense system and histological changes of pancreatic $\beta$-cells ... Drug and chemical toxicology. 2010;33(2):120-130. doi: 10.3109/01480540903203984

35. Nozaki Y, Yamagata T, Sugiyama M, Ikoma S, Kinoshita K, Funauchi M. Anti-inflammatory effect of all-trans-retinoic acid in inflammatory arthritis. Clinical immunology. 2006;119:272-9. doi: 10.1016/j. clim.2005.11.012

36. Ohkawa H, Ohishi N, Yagi K. Assay for lipid peroxides in animal tissues by thiobarbituric acid reaction. Anal Biochem. 1979;95(2):351-8. doi: 10.1016/00032697(79)90738-3

37. Osman AEG, Jennifer A, Jane EC, et al. Treatment of Acute PromyelocyticLeukemia in Adults. J. Oncol. Pract. 2018;14(11): 649-657. doi: 10.1200/JOP.18.00328

38. Palace VP, Khaper N, Qin Q, Singal PK. Antioxidant potentials of vitamin $A$ and carotenoids and their relevance to heart disease. Free RadicBiol Med. 1999;26(5-6):746-61. PMID: 10218665. doi: 10.1016/ S0891-5849(98)00266-4

39. Puigserver $\mathrm{P}$, Vázquez $\mathrm{F}$, Bonet ML, Picó $\mathrm{C}$, Palou $\mathrm{A}$. In vitro and in vivo induction of brown adipocyte uncoupling protein (thermogenin) by retinoic acid. Biochem J. 1996;317:827-833. doi: 10.1042/bj3170827

40. Rafa H, Benkhelifa S, Younes SA, et al. All-Trans Retinoic Acid Modulates TLR4/NF- $K B$ Signaling Pathway Targeting TNF- $\alpha$ and Nitric Oxide Synthase 2 Expression in Colonic Mucosa during Ulcerative Colitis and Colitis Associated Cancer. Mediators of Inflamm. 2017;7353252. doi: 10.1155/2017/7353252

41. Ribot J, Felipe F, Bonet ML, Palou A. Changes of adiposity in response to vitamin $A$ status correlate with changes of PPAR gamma 2 expression. Obes Res. 2001;9:500-509. doi: 10.1038/oby.2001.65

42. Romero C, Desai P, DeLillo N, Vancura A. Expression of FLR1 transporter requires phospholipase $C$ and is repressed by Mediator. J Biol Chem. 2006;281(9):567785. doi: $10.1074 /$ jbc.M506728200

43. Rotruck JT, Pope AL, Ganther HE, Swanson AB, Hafeman
DG, Hoekstra WG. Selenium: biochemical role as a component of glutathione peroxidase. Science. 1973;179(4073):588-90. PMID: 4686466. doi: 10.1126/ science.179.4073.588

44. Sano $\mathrm{H}$, Kawahito $\mathrm{Y}$, Wilder RL, et al. Expression of cyclooxygenase-1 and -2 in human colorectal cancer. Cancer Res. 1995;55(17):3785-9. PMID: 7641194.

45. Sinha AK. Colorimetric assay of catalase. Anal Biochem. 1972;47(2):389-94. doi: 10.1016/00032697(72)90132-7

46. Suzuki T, Hara I, Nakano M, et al. Site-specific labeling of cytoplasmic peptide: $\mathrm{N}$-glycanase by $\mathrm{N}, \mathrm{N}^{\prime}$-diacetylchitobiose-related compounds. J Biol Chem. 2006;281(31):22152-60. doi: 10.1074/jbc. M603236200

47. Vaidya FU, Chhipa AS, Sagar N, Pathak C. Oxidative Stress and Inflammation Can Fuel Cancer. In: Maurya P., Dua K. (eds) Role of Oxidative Stress in Pathophysiology of Diseases. Springer, Singapore. 2020. doi: 10.1007/978-981-15-1568-2_14

48. Valavanidis A, Vlachogianni T, Fiotakis $\mathrm{K}$, Loridas $\mathrm{S}$. Pulmonary oxidative stress, inflammation and cancer: respirable particulate matter, fibrous dusts and ozone as major causes of lung carcinogenesis through reactive oxygen species mechanisms. Int J Environ Res Public Health. 2013;10(9):3886-3907. doi: 10.3390/ ijerph10093886

49. Villarroya F, Iglesias R, Giralt M. Retinoids and retinoid receptors in the control of energy balance: novel pharmacological strategies in obesity and diabetes. Curr Med Chem. 2004;11:795-805. doi: 10.2174/0929867043455747

50. Watkins, AL, Hillison W, Morecroft SE. Audit quality: A Synthesis of theory and empirical evidence. Journal of Accounting Literature. 2004;23: 153-193.

51. Weinberg F, Ramnath N, Nagrath D. Reactive Oxygen Species in the Tumor Microenvironment: An Overview. Cancers. 2019;11(8):1191. doi: 10.3390/ cancers11081191

52. Wu S, Donigan A, Platsoucas CD, Jung W, Soprano DR, Soprano KJ. All-trans retinoic acid blocks cell cycle progression of human ovarian adenocarcinoma cells at late G-1. Exp Cell Res. 1997;232: 277-286. doi: 10.1006/ excr.1997.3495

53. Zhang $X$, Liu L, Yao $Y$, et al. Treatment of non-high-risk acute promyelocyticleukemia with realgar-indigo naturalis formula (RIF) and all-trans retinoid acid (ATRA): study protocol for a randomized controlled trial. Trials. 2020;21:7. doi: 10.1186/s13063-019-39832

54. Zuccari G, Carosio R, Fini A, Montaldo PG, Orienti I. Modified polyvinylalcohol for encapsulation of alltransretinoic acid in polymeric micelles. J Control Rel. 2005;103: 369-380. doi: 10.1016/j.jconrel.2004.12.016 